
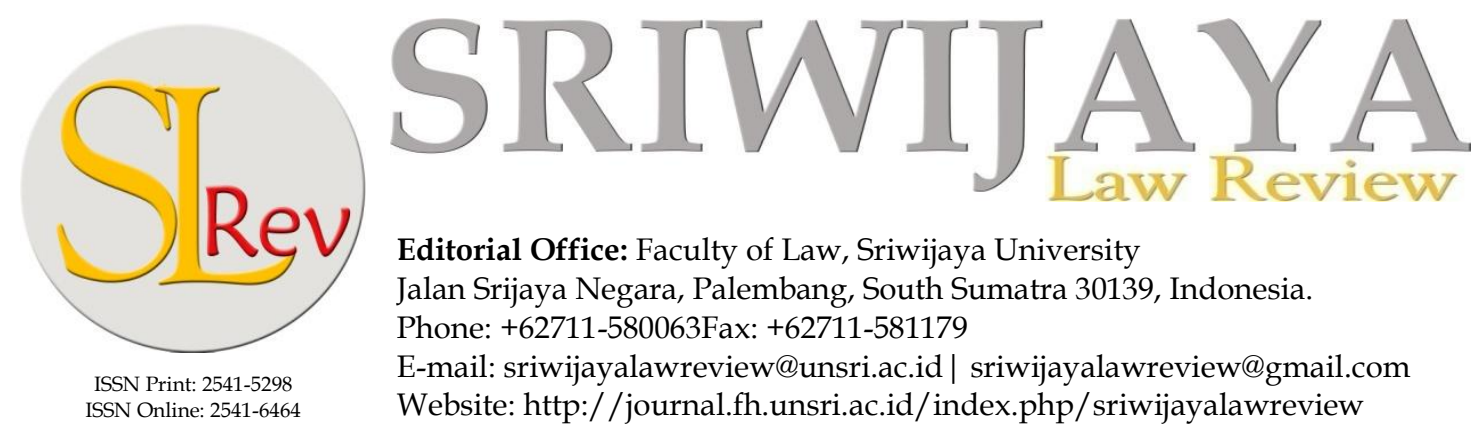

Editorial Office: Faculty of Law, Sriwijaya University

Jalan Srijaya Negara, Palembang, South Sumatra 30139, Indonesia.

Phone: +62711-580063Fax: +62711-581179

E-mail: sriwijayalawreview@unsri.ac.id | sriwijayalawreview@gmail.com

Website: http://journal.fh.unsri.ac.id/index.php/sriwijayalawreview

\title{
Law Enforcement of The Bandung Regional Regulations on The Orderliness, Cleanliness, and The Beauty
}

\author{
Yesmil Anwar, ${ }^{1}$ Somawijaya, ${ }^{2}$ Sigid Suseno, ${ }^{3}$ and Nella Sumika Putri ${ }^{4}$
}

\begin{abstract}
Sidewalk vendor is one of the main contributors to the dirtiness and traffic congestion in Bandung. Bandung has passed a Regional Regulation Numbered 3 and 5 about Cleanliness, Orderliness and the Beauty to prevent and to build the sidewalk vendors. However, lack of legal awareness and law enforcement may constrain the effectiveness of the regulation. Those regulations are particularly Bandung Regional Regulation Numbered 4/ 2011 concerning sidewalk vendors in which imposing high fine sanction not only for the seller but also for the buyer to prevent them from violating those regulations. To analyze the the compliance level of society and the effectiveness of fine sanction for the violation of regulations, this research used juridical normative approach and comparative method by comparing the regulation in Bandung with other Regional regulations related to sidewalk vendors in other cities in Indonesia such as in Surakarta and Surabaya. This research found that the law enforcement to the violation of sidewalk vendors regulation in Bandung city is not optimum due to lack of awareness to obey the law. The criminal sanction such as fine and forced fees are not able to prevent the violation of sidewalk vendors regulations. This research suggest that The Regional government of Bandung City: (1) needs to find a right model to keep sidewalk vendors in order by looking at the characteristics of the society and its social culture; (2) needs to search for a way to increase society's compliance to any policies made by the government; and (3) needs to revise the current regulation.
\end{abstract}

Keywords: Cleanliness; law enforcement; regional regulations.

\section{ARTICLE HISTORY:}

Received:

Dec 13, 2016; Reviewed: Dec 20, 2016

Accepted:

Dec 27, 2016; Published: Jan 30, 2017

Faculty of Law, Padjadjaran University

Faculty of Law, Padjadjaran

University

3 Faculty of Law, Padjadjaran

University

4 Faculty of Law, Padjadjaran University, Email: nellasumikaputri@yahoo.com

\section{INTRODUCTION}

Bandung has been popular as "Paris Van Java" which is well-known for its beauty and cleanliness so that since long Bandung has been the tourist main destination. The tourists come either from around Indonesia or abroad. Tourists come to spend their vacation and some domestic tourists come to continue their study to universities or 
institutes. ${ }^{1}$ Bandung itself has been a service city and when we see it from the city vision, Bandung is oriented as a service city which values discipline and orderliness, cleanliness and the beauty of the city. And to achieve such goal, The Government of Bandung issued Regional Regulations Numbered 03/ 2005 regarding the administering of Orderliness, Cleanliness and the beauty as later is referred to as Regional Regulation numbered 11/ 2005 regarding the administering of Orderliness, Cleanliness and the Beauty. Bandung is an urban area which covers $16,767 \mathrm{Km} 2$. It is divided into 30 sub-districts and 151 urban villages. ${ }^{2}$ Bandung residents referring to Bandung Central Bureau of Statistics (BPS) of 2009 was 2,402,215 residents with average population growth of $1.42 \%$. The level of Population Density of Bandung City is 44,792 persons $/ \mathrm{Km}^{2}$. Therefore, Bandung can be categorized as a densely populated city. The Chairman of Indonesian Planner Association Bernardus Djonoputro stated that Bandung is one of the cities besides Jakarta which has the lowest level of public perception. Bandung has an extremely bad city planning problem: having a very minimum green open space with very high level of polluted environment; bad and inadequate public transportation, dirty surrounding due to the scattered garbage around the city. ${ }^{3}$

1 There are two government owned universities in Bandung namely Universitas Padjadjaran and Institut Teknologi Bandung.

2 Local government regulation of Bandung City numbered 06 / 2006 on the expansion and the formation of sub-districts and urban villagesin Bandung City Government.

http://properti.kompas.com/read/2014/03/26/ 1540003/Bandung.dan.Jakarta.Kota.Terburuk.di.I ndonesia (retrieved: April 29, 2014).
Therefore based on the above fact, the problems such as road orderliness, public facilities and green open space have become crucial problems in Bandung as a service city. Regional Government through Regional Government Regulation Numbered 03 and numbered 11 of 2005 of Bandung City put its efforts to regulate the violators who causes inconvenience the traffic users of Bandung city. The measures include to regulate the traffic, the pavements, the sidewalks including to regulate the green open space, crossing bridges which so far annoy the street users particularly pedestrians and other street users. Some hot issues connecting to the implementation of high amount of fine in Bandung city is the occurrence of sidewalk vendors who operate in red zone in Bandung such as Jalan Merdeka, Jalan Dipenogoro, or Jalan Kepatihan areas. Eventhough the sidewalk vendors in these areas have alreadybeen regulated and there are sign boards which state the notice not to operate around the areas have several times been informed, the sidewalk vendors still run their selling activities in and around the area. The Regional government regulation numbered 03 and Numbered 11 of 2005 of Bandung city basically have imposed sanction which varies from the amount of fine of $\mathrm{Rp}$. 250.000,- up to Rp. 50.000.000,- for violations like among others: a $\mathrm{Rp}$. 250.000,- fine when they litter, a fine of Rp. 1000.000 ,- when selling on sideways or on the street or a fine of Rp. 10.000.000 when they commit an act of vandalism to destroy public facilities.

1. Considering those facts, researchers tried to formulate some problems which will be solved by the research. The problems are as follow: How the 
implementation of Regional govenrment regulations on orderliness, cleanliness and the beauty towards the sidewalk vendors who violate the Regional government regulations regarding the violation of street orderliness, public facility and green open space?

2. What factors which make sidewalks vendors do not obey Regional Government Regulations regarding rules of street orderliness, public facility and green open space?

3. Can criminal sanction avoid the occurrence of violations to the Regional government by the sidewalk vendors?

\section{ANALYSIS AND DISCUSSION}

\section{Literature Review}

To answer the questions, we use several theories of law such as:

The answer to the questions concerning the obstacles occuring in the process of law enforcement of Regional government regulations on orderliness, cleanliness and the beauty is related to, among others, the mechanism of law enforcement. The process of law enforcement is not an easy thing to do. It depends on several factors such as society expectation factor and society motivation to actively participate in the process of law enforcement. ${ }^{4}$ The law enforcement itself should consider law certainty, usefulness and justice. ${ }^{5}$ The existence of regulations expects society who becomes the target of the regulations to act

4 Soerjono Soekanto, Faktor-Faktor yang Mempengaruhi Penegakan Hukum, Raja Grafindo Persada, 1983. p 60.

5 Sudikno Mertokusumo, Bab-Bab tentang Penemuan Hukum, Citra Aditya Bakti, Jogja, 1993. p 1. accordingly as determined in the regulations which are regulated by law. ${ }^{6}$

Criminal Law enforcement is an integral part of law enforcement in general. Soerjono Soekanto pointed out that the essence and the meaning of law enforcement lies on activities which keep the harmony of explained values in correlation with steady and applicable rules and actions since the implementation of final stage of values to create, to keep and to nurture peace in social interaction. $^{7}$

Therefore, law enforcement is not only about how the law enforcers apply exixting law but they should also consider other factors which affects the application. Factors which can influence law enforcement are laws, law enforcers, facilities and infrastructures which support society and culture. This is in line with what is stated by Soerjono Soekanto regarding factors which affect the effectiveness of law validity, which are: ${ }^{8}$

1. The law factor itself;

2. Law enforcer factor: are those who establish and enforce law;

3. Facilities and infrastructures which support law enforcement;

4. Society factor, that is where the law is implemented and enforced;

5. Culture factor, that is the result of creation produced from thinking and feelingwhich are based on people's intention in society.

6 Hans Kelsen dalam Jimly Asshiddiqie dan M Ali Safa'at, Teori Hans Kelsen Tentang Hukum", Sekretariat Jenderal dan Kepaniteraan, Mahkamah Konstitusi RI, 2006. p 15.

7 Soerjono Soekanto, Faktor-Faktor yang Mempengaruhi Penegakan Hukum (Pidato Pengukuhan sebagai Guru Besar pada Fakultas Hukum Universitas Indonesia), PT RajaGrafindo Persada, Jakarta, 2008. p 5.

8 Soerjono Soekanto, Note 1. p 8. 
This research is trying to analyze all factors which influence law enforcement in the implementation of Regional government regulations on orderliness, cleanliness and the beauty so that we obtain certain facts regarding factors which effectively obstruct the implementation of Regional government regulations on orderliness, cleanliness and the beauty.

Robert Eyestone ${ }^{9}$ explaines that public policy is a relationship between government unit and its surroundings, and the interaction between the state and its citizen which prevails in a process to overcome public issues. This statement is in agrement with the statement given by Carl Friedrich ${ }^{10}$ who defines public policy as government intervention by empowering various instruments like society (either in group or individual) to overcome public issues. Dye, defines public policy as government option to do or not to do something. ${ }^{11}$

To realize public policy, government has to implement public policy. To execute the implementatin of public policy, we need suppoting factors such as legal administrative means such as organization, procedure and techniques which work together to achive the goal. ${ }^{12}$

Regional Government Regulations can rule action which is subject to criminal sanction. The policy of criminal sanction in Regional government regulation is a part of criminal policy. To criminalize an action in Regional government regulation, the policy maker must consider parameter in criminali-

\footnotetext{
9 Budi Winarno, Apakah Kebijakan Publik? Dalam Teori dan Proses Kebijakan Publik, Media Pressindo, Yogyakarta, 2002. p 15.

10 Budi Winarno. Note 9. p 16.

11 Budi Winarno. Note 9. P 16

12 Budi Winarno. Note 9. p 102.
}

zation. The Guidelines in criminali-zation are as follows ${ }^{13}$ :

1. Criminalization should not give an impression of over criminalization which includes in the category of the misuse of criminal sanction.

2. Criminalization should not havead hoc character

3. Criminalization should contain victim factor (victimizing) either as actual or potential.

4. Criminalization should calculate cost analysis and result analysis based on ultimumremedium principle.

5. Criminalization should result in enforceable regulation.

6. Criminalization should be able to obtain public support.

7. Criminalization should contain subsosial factor (causing danger to society eventhough the factor occurs in a small portion)

8. Criminalization should consider that every criminal rule limits individual freedom and it gives to the law enforcer possibility to limit the freedom.

\section{Research Method}

Approach method used was juridical normative or it is also known as library research $^{14}$. Besides juridical normative approach, it was preceded by searching legal principles and rules which can be found in Criminal Law, and Criminogy and Sociology. This research used specific method of

\footnotetext{
13 Muladi, Kapita Selekta Hukum Pidana, Badan Penerbit Universitas Diponegoro, Semarang, 1995. p 256

14 Soerjono Soekanto dan Sri Mamudji, Penelitian Hukum Normatif suatu Tinjauan Singkat, Publisher Rajawali, Jakarta, 1985. p 15.
} 
descriptive analysis ${ }^{15}$ to describe or to explain existing facts in a form of secondary data or primary data by using primary, secondary or tertiary law materials. ${ }^{16}$ The research also used the method of comparatives studies/law comparison to carry out an analysis in some areas in making a policy to regulate and to establish an order society such as in Surakarta and Surabaya.

\section{Results and Discussion}

We conducted several activities as the effort to obtain answers to the issues being investigated in this research. The writers conducted research in Surabaya and Surakarta. These two cities are comparative cities considering that in these two cities we can obtain the information from previous research concerning the law enforcement to the sidewalk vendors which have been very successful and those cities have significant success in handling sidewalk vendor problems, and the most successful cities which can overcome sidewalk vendors problems in Indonesia. Below, we can find the analysis of problems which become problem identification:

\section{The implementation of Regional} Government Regulation on Orderliness, Cleanliness and the Beauty to sidewalk vendors who commited violation regarding street orderliness, public facilities and green line:

Regulating and Advocating which includes regulating sidewalk vendors covers a lot of things which are related to matters concer-

15 Soerjono Soekanto, Pengantar Penelitian Hukum Edisi Kedua, UI Press, Jakarta, 1982. p 50.

16 Ronny Hanitjo Soemitro, Metodologi Penelitian Hukum dan Jurimetri, Ghalia, Jakarta, 1990. pp 11-12 ning orderliness, the beauty, clean-liness, city zoning, economics, and matters concerning crime. The occurrence of sidewalk vendors when we see it from regulation point of view, is considered an action which violates law since the action creates disturbance to traffic order particularly disturbing pedestrians. ${ }^{17}$

The effort to keep sidewalk vendors in orderly fashion has basically been conducted by Bandung government for long time through legislation. This matter is stipulated in Regional Government Regulation numbered 3 / 2005 and Regional Government Regulation numbered 11 / 2005 regarding the implementation of orderliness, cleanliness and the beauty. Specifically, the regulation of the occurrence of sidewalk vendors in Bandung City can be found in Regional Government Regulation numbered 4 of 2011 regarding regulation and advocation of sidewalk vendors. Matters regarding what is meant by sidewalk vendors is mentioned in Regional government regulation and referring to the definition of sidewalk vendors in Regional Government Regulation numbered 4 of 2005, Sidewalk vendors are sellers who run selling activity in informal sector, using the facility of public, with or without moving carts. This definition is given more detailed in Article 10 where it mentions that the characteristics of sidewalk vendors includings idewalk vendors classifications. The classifications include merchandise or goods sold, time of operation and techniques to sell the goods.

\footnotetext{
17 Tulus Haryono, Faktor-Faktor yang Mempengaruhi Keberhasilan Usaha Pedagang Kaki Lima, Studi Kasus di Kodya Surakarta, UGM Press, Yogyakarta, 1989.
} 
Regulating and advocating sidewalk vendors in Bandung City are under the authority of Vice Mayor who manages (under him) Regional Government Agency which is in charge of special task force handling sidewalk vendors management. This special task force manages planning under the coordination of the Regional Development Planning Agency/ Bappeda which arranges sidewalk vendors in coordination with Human Settlements and Spatial Planning Agency/ Distarcip; advocation under the Cooperative, Industry and Trading Agency/ Diskoperindag; promotion of sidewalk vendors in coordination with Culture and Tourism Agency/ Disbudpar; and supervision of the control and law enforcement in coordination with Civil Service Police Unit of Bandung City.

Based on discussion and interview with Civil Service Police Unit of Bandung City, we can draw a conclusion that regulating sidewalk vendor basically has been carried out in persuasive manner but later the number of sidewalk vendors grew in number. In April 2014, the number of sidewalk vendors reached 16,195 vendors in sub-district areas. While the number of sidewalk vendors in Gasibu, referring to District Military Command/Kodim 0618/BS was 2,478 so that the total number of sidewalk vendors reached 18,673 vendors. ${ }^{18}$ This persuasive mechanism was hard to be carried out since there was third party who hampered the process of regulating the sidewalk vendors. The third parties received high income from the sidewalk vendor activity and with the regulation of sidewalk vendors, it means that they will lose their

18 http://www.bandung.go.id/rwd/index.php?fa= berita.detail\&id=2329. (retrieved: October 20, 2015). income from parking charge or from illegal retribution that they have illegally imposed to sidewalk vendors through arbitrary and forceful practices. Special task force whichshould regulate is the force which deals with planning, regulating and advocating sidewalk vendors but in fact the one who carries out the actions is civil service police unit who, in this matter, acts as a law enforcer. Therefore, the approach used to regulate sidewalk vendors was using repressive mechanism.

One of the obstacles is sidewalk vendor characteristic in Bandung City which is varied so that sosiological approach which is carried out tend to be less effective and the blame is to culture. Represive effort is considered to give more significant effects in regulating mechanism eventhough the action often causes loss in both sides. When compared to the process of regulating sidewalk vendors in Surabaya and Surakarta, the policy taken by Bandung City Government should be in persuasive characteristic and the policy should prioritize sosiological consideration but not only emphasizing on law enforcement. This action should be taken to minimize loss to both sides. Besides that, government of Bandung city should also harmonize Regional government regulations which regulates sidewalk vendors with national legislation and regulation in view of the facts that the types and characteristics of sidewalk vendors keep developing. We often found different definition including too detailed definition so that when there is a developing type of sidewalk vendors who uses motorized carts like food trucks, this kind of sidewalk vendors are not included as subject of existing regulation. 
Dissemination of the regulation banning sidewalk vendors has not been carried out consistently and sustainably. This effort includes finding areas to relocate sidewalk vendors. The most important things to be considered in regulating sidewalk vendors are planning and funding which should clearly be determined by the urban development considering that Bandung has limited space and also has environmental problems concerning garbage and pollution. Dissemination of the regulation and advocation of sidewalk vendors are not only imposed to vendors but also imposed to the buyers who feel that regulating sidewalk vendor makes them inconvenient and make vendors are hard to find. Law enforcement to sidewalk vendors should continuously be done and it should not only be done seasonally. If it does, it will cause inconsistency to law enforcement. The level of compliance of Bandung people, particularly sidewalk vendors is still low. Even if obeyingregulation is only part of compliance. People only comply with regulations because of its sactions, in this case, being the one who is the subjest of sweeping or being the subject of fine or forced payment which really threaten them. When regulating process occurs, people try to ovoid doing violation so they are free from sanction, but when regulation is not enforced sidewalk vendors go back with the activity that violates the regulation.

During the sweeping of sidewalk vendors, the sidewalk vendors avoid from having legal action, but when the civil service police unit officers are careless, the sidewalk vendors return to do what they have done. Civil service police unit as the law enforcer, so far, has not had sufficient human resource. Civil Service Police Unit of
Bandung City nowadays has 385 personnels and not all of them are in the field. Ideally the number of civil service police unit of Bandung City should be 1,500 personnels in comparison with the number of Bandung residents which has reached 2.5 million people. ${ }^{19}$ In respect to the pattern of civil law obedience either the sidewalk vendors or buyers who still maintain compliant obedience pattern, the role of civil service police unit is deemed necessary because this model needs continuous monitoring. ${ }^{20}$

Currently sidewalk vendor problem in Bandung City is not merely in economy but more than that which is the change of law culture especially community law culture either sellers or buyers in doing their economic activities in designated places. The change of law culture cannot be done in represive way but must be carried out through comprehensive cultural approach. Cultural change cannot be done in a short time but must be done continously and sustainably.

Factors causing sidewalk vendors in Bandung not to abide Regional Government Regulation on Order, Cleanliness and Esthetic in relation to the regulations of street order, public facilities and green line

The main determining factor for the success of the level of compliance of sidewalk vendors really depends on the leadership of the Regional government leader. To assess

19 Result of interview and data finding at Bandung City Civil Service Police Unit, Henry Kusuma as resource person, on 22nd October 2015.

20 Achmad Ali, Menguak Teori Hukum (legal Theory) dan Teori Peradilan (Judicialprudence) Termasuk Interpretasi Undang-Undang (Legisprudence), Kencana Prenada, Jakarta, 2012. p 348. 
community's compliance towards the authority in Bandung City area, the statistical data of sidewalk vendors in Bandung city should come into consideration. According to the data of the Agency of Cooperative, Industry and Trade of Bandung City in 2013, the number of sidewalk vendors in Bandung City reached 20,326 people. $^{21}$

Based on the results of the research carried out in 4 different sidewalk vendor areas in Bandung City (the areas of Cicadas, Tegalega, Sukajadi and Burangrang) in 2014 , the total number of sidewalk vendors was 9,118 comprising $76.21 \%$ men and $23.79 \%$ women. The majority of sidewalk vendors $(32,12 \%)$ was at the productive ages between 25 to $34 ; 15$ to 24 years was at $14.77 \%$; and above 55 yearswas at $8.06 \%$. In those four places, the majority of sidewalk vendors had the education level of junior high school (35.7\%) with the total of 3,255 people;the lowest percentage was those who were educated up to bachelor degree $(0.72 \%)$ reaching 66 people; at the level of senior high school at the number of 2,890 people; at the level of elementary school at the number of 2,544 people; and those who were uneducated were as many as 287 people; and there was no sidewalk vendor in the areas who were educated up to master or doctoral degrees. ${ }^{22}$ From 9,118 sidewalk vendors in the areas, most of them were Sundanese tribe as many as 7,764 people $(85.15 \%)$; Javanese tribe as many as

21 http://ayobandung.com/read/20150714/59/ 786/mengkhawatirkan-jumlah-pkl-bandungmelebihi-pedagang-formal. (retrieved: October 20, 2015).

$22 \mathrm{http} / / / \mathrm{www}$. sinarpaginews.com/fullpost/ bandung/1409058971/pemkot-bandung-lakukanekpose-dan-penataan-pkl.html. (retrieved: October 20, 2015).
904 people $(9,91 \%)$; Bataknese tribe as many as 93 people; Padangnese tribe as many as 220 people; Ambonese tribe as many as 11 people; and the rest were Betawinese, Madurese, Palembangnese and Lampungnese who reached $126 .{ }^{23}$

If we analyze the origins of the sidewalk vendors from 4 areas in Bandung, we can conclude that the sidewalk vendors who run the business came from out of Bandung eventhough most of them were Sundanese but not all possesed Bandung City identity card. Generally they came from the areas around Bandung such as Bandung Regency, Sumedang, Subang and so on. According to the interview with the resource person in Bandung City Civil Service Police Unit, the fact shows that the ratio between the sidewalk vendors coming from out of Bandung is almost balanced with with those coming from Bandung City (based on Bandung City identity card ownership).

In general, those who do not abide the authority or respect to the regulations are non-residents of Bandung, while Regional residents have more tendency to abide and respect to the authority. This brings to a conclusion that the origin of sidewalk vendors is important to measure the compliance level. Sidewalk vendors who were born and raised in Bandung and posses Bandung identification card have the tendency to be obedient rather than those of non-residents and live temporarily because those non-residents do not have the sense of belonginness and close feeling with Bandung City. ${ }^{24}$

\footnotetext{
Note 22.

24 Interview with Henry Kusuma, an officer of Civil Service Police Unitof Bandung City.
} 
If we view from the theory of public policy, the factors causing the sidewalk vendors fornon-compliant to the regulations are as follows:

\section{There is an awareness to accept the policies}

The shaping of society's awareness to abide any policies regulated by the Regional government is pretty hard to be realized. Most sidewalk vendors are Regional people whereas Bandung City has almost half of its residents are non-residents so that the level of their awareness to accept policies is low. The origin of sidewalk vendors has a substantive influence to the level of awareness to accept the policies because society in each place has its different behaviors which prevail in respective societyso that each place has different behaviors prevailing in differentgroups in the society. Thus, a behavior which prevails in a certain society does not necessarily prevails in a another group of another society. $^{25}$

To evaluate whether the society (sidewalk vendors) of Bandung has the awareness towards the existing policies or not remains on their knowledge of law or regulations. The people of Bandung City, either sidewalk vendors or buyers should have been informed about the Regional Government Regulation on Order, Cleanliness and Estheticand Regional Government Regulation on Sidewalk Vendors in Red Zone. This can be seen from the announcements on the banners and

25 Elly M Setiadi and Usman Kolip, Pengantar Sosiologi, Pemahaman Fakta dan Gejala Permasalahan Sosial: Teori Aplikasi dan Pemecahannya, Kencana Prenada Media Group, Jakarta, 2013. p 115. electronic media. The Regional government of Bandung City already made dissemination activity (especially funded) in conjunction with local sub-district government. The second indicator is the law awareness which involvesthe understanding of law. The understanding of law itself is very subjective depending on each individual of his/her understanding that fundamentally making a living by selling is not restricted but there must be a regulation on the place and time especially in red and yellow zones in the framework of public order.

The third indicator to evaluate law awareness is the attitude of society towards the law. Basically there are 2 opinions of sidewalk vendors concerning the Regional Government Regulation on Order, Cleanliness and Esthetic and Regional Government Regulation on Sidewalk Vendors. Sidewalk vendors who happen to be the residents of Bandung City have the tendency to be compliant compared to those who came from out of the city so that there must be a solution to overcome the problem of sidewalk vendors coming from out of Bandung City.The last indicator is legal and non-compliant behaviors of the sidewalk vendors which really depend on each individual. These behaviors can be influenced from external factors such as the attitude of immitating and being sceptical to law.

Society is certain that the policies were enacted rightfully, validly and legally by the authorized institutions

Dissemination activity and approach which is done by the Regional government to the sidewalk vendors before the relocation has made the sidewalk vendors sure that the 
existing regulations to uphold order and manage the sidewalk vendors are truely made, approved and implemented by the authorized institutions. The institutions directly carry out the mechanisms of upholding and implementing orderliness. To reach the target, a mechanism should be done by disseminating the information to the involved parties continuously.

\section{Based on the society's interest}

Eventhough there is a perception that the government policy to manage sidewalk vendors is a policy which is considered as if to take away the right of the society to earn money, but through persuasive measures carried out by the Regional government, the policy in fact protect the society itself. For Bandung City, considering the city's pluralism and high movement either its people or economy, policy makers should be able to identify what the society needs. Policy making by the governement should consider antropological and sociological aspects before enacting or implementing its policies.

\section{Sanctions towards violations made}

Basically Regional government regulation imposes high sanction to any sidewalk vendor who violates. Regional Government Regulation numbered 4 of 2011 regulates high fine as much as Rp. 1,000,000.- for a buyer besides administrative sanctions in the form of annulment of identification, closing or dismantling of the place to run business for the sidewalk vendors. Up to know the actions of law enforcement conducted by the government in keeping order of sidewalk vendors through represive measure have not reached to impose fine as much as the maximum amount regulated by the laws.
This is because the government prioritizes consensus and administrative mechanisms in order the society becomes more compliant to the existing regulations. Even if there is a violation, the violation is considered as breaching the written agreement between the government and the sidewalk vendors themselves. Besides that, the sanction with the high fine to be payed by the people becomes ineffective because people cannot afford to pay it.

Fine sanction to avoid the violation of the Regional Government Regulation on Order, Cleanliness and Esthetic by the sidewalk vendors

Pertaining to the Regional Government Regulation on Order, Cleanliness and Esthetic of Bandung City,selling activity carried out by the sidewalk vendors is not a violation. Sidewalk vendor's activity becomes a violation when the sidewalk vendor runs his/her business or sell his/her products on the sidewalk, street, street side, park, green line and other places which are not intended for that purpose. For the violation, the sidewalk vendors is subject to a fine amounting Rp.1,000,000.- aside from the administrative measure. ${ }^{26}$ Besides the fine, the violator can be sentenced to a 3- month confinement or fine as much as Rp. $50,000,000 .-$. As for the buyer who is involved in the transaction in the restricted zone is subject to a fine as much as Rp. $1,000,000 .-.^{27}$

26 See Article 49 (1), The District Regulation of Bandung No. 11 of 2005 on the Change of The District Regulation No. 3 of 2005 on the Administration of Orderliness, Cleanliness and the Beauty.

27 See Article 24 point 1 and 2, The District Regulation of Bandung No 4 of 2011 on the 
Eventhough the Regional Government Regulation gives sanctions to the sidewalk vendors of Bandung City either in the form of fine or confinement, the sanctions are hardly carried out because the Regional government takes up persuasive mechanism. According to the field study, the prevention of the violation of sidewalk vendors in Bandung City is not fully by imposing sanctions but giving priority on settlement of the root problems.

The sanctions in the form of fine, so far, according to the results of the research, has not provided a significant change towards the prevention of violations made by the sidewalk vendors or the buyers.In Bandung City, the sanction given to the violaters, so far, was only imposing fine to the violators not as much as the regulated fine stipulated by the Regional government regulation. At average, the fine cost not more than Rp. 250,000 .

If referring to the measurement of criminalization put forward by Muladi, the criminalization of sidewalk vendors and their buyers does not meet the criminalization measurement. The first reason is concerning the victim. The victims of sidewalk vendors cannot be clearly identified even though there are people who are disrupted especially pedestrians whose right to walk on the sidewalk is disturbed since sidewalk is used by the sidewalk vendors but on the other hand most pedestrians do not mind with the existence of the sidewalk vendors even they are fortunate with the sidewalk vendors' activity in the area because people have the easy access to purchase certain products. The

Arrangement and Supervision of Sidewalk Vendors. existence of sidewalk vendors as a small scale business is also a solution to the increasing number of unemployment at the time when the Regional government is unable to provide work field. ${ }^{28}$

Second reason is that the Regional Government Regulation on Order, Cleanliness and the Beauty and Regional Government Regulation on Sidewalk Vendors are not enforceable regulations. This can be viewed from the inconsistency of law enforcement in the field. The amount of fine which is considered high has not been applied as it should be so that people think that the Regional Government Regulation on Order, Cleanliness and the Beauty and Regional Government Regulation on Sidewalk Vendorsare merely recommendation without law enforcement. Third reason is that the Regional Government Regulation on Order, Cleanliness and the Beauty and Regional Government Regulation on Sidewalk Vendors have not received any public supportf if this is correlated to the previous analysison society's law awareness. The society of Bandung City has not considered criminalizing sidewalk vendors through criminal sanction in the form of fine as something which is not necessary right now including the impact of allowing the sidewalk vendors to continue having their activities in the places which are restricted. Besides that it can also cause traffic congestion and not to mention (based on the next criminalization measure) the danger factor as the result of sidewalk vendor activities such as disease

28 Dinarjati Eka Puspitasari, "Penataan Pedagang Kaki Lima Kuliner untuk Mewujudkan Fungsi Tata Ruang Kota di Yogyakarta dan Kabupaten Sleman," Mimbar Hukum, Volume 22, Number 3, October 2010. p 596. 
caused by garbage, illegal fee collection or becoming prostitution place (as a case in Surakarta) which later cause the decrease of land value and the spread of venereal disease.

The criminal sanction in the form of fine surely correlates with the problem of law enforcement in which the government apparatuses posses the authority to limit the right of citizens. The possible problem from this authority is the arbitrary measures which oftentimes cause loss not only to the sidewalk vendors but also the apparatuses themselves.Lack of knowledge and capacity from the civil service police unit officers may cause negative impacts in the framework of law enforcement such as seizure, beating, etc.

The review on fine sanction correlates with the inneffectiveness of its implementation all this time and whether at the time when formulating a certain criminal sanction, has there been a review on the balance between action and criminal sanction. This is in line with the Desert Theory or the theory of reward. ${ }^{29}$ Based on the Desert Theory, there must be equilibrium between fault and punishment. Fault is an abstract thing so that it is difficult to judge and it is closely related to a category crime committed. ${ }^{30}$

The activities of sidewalk vendors done in restricted zones fall into the category of light violation because ${ }^{31}$ :

1. The value of material loss as the impact of the action is almost none if it is directly observed;

29 Eva Achjani Zulfa, Pergeseran Paradigma Pemidanaan, Lubak Agung, Bandung, 2011. p 38.

30 Eva Achjani Zulfa. Note 29. p 39.
2. Part of society still has the perception that the existence of sidewalk vendors is not something to be banned eventhough they cause traffic jams and produce garbage but people still need them because they make people easy to do buying and selling activities.

3. In the question of whether there are victims of sidewalk vendors, actually not directly but more to the impact related to traffic orderliness, the right of street users and cleanliness.

4. The method used by the sidewalk vendors is only manipulating the weakness of law enforcers who do not consistently monitor restricted zones for sidewalk vendors.

The criminalization of sidewalk vendors by imposing fine or forced payment will not give impact if there is lack of consistency in law enforcement and society's legal awareness increases. So, based on above analysis, the regulation to criminalize sidewalk vendors does not meet the criteria of criminalization itself. There should be a review on the regulation of criminal sanction in the Regional Government Regulation on Order, Cleanliness and the Beauty, and Regional Government Regulation on Sidewalk Vendors.

\section{CONCLUSION}

According to the explanation above, it can be concluded that:

1. The implementation of the Regional Government Regulation on Order, Cleanliness and the Beauty to the sidewalk vendors who violate traffic orderliness, public facilities and green line has not been implemented maximumly. To maximize the imple- 
mentation of the Regional Government Regulation on Order, Cleanliness and the Beauty to the sidewalk vendors, persuasive approach is needed which prioritize the communication between both parties by paying attention to sociological, cultural and humane aspects.

2. Determining factors which make sidewalk vendors of Bandung City do not abide the Regional Government Regulation on Order, Cleanliness and the Beauty concerning street orderliness, public facilites and green line are the sidewalk vendors who do not have respect or have lesser respect to the authority and to the decisions made by government institutions; lack of society's legal awareness; society (sidewalk vendors) who just think about themselves; and exaggerated sanctions. In brief, it can be concluded that the level of legal awareness and legal abiding of society is still low.

3. High fine sanction and forced payment are not the solutions to avoid the violation of the Regional Government Regulation on Order, Cleanliness and the Beauty by the sidewalk vendors.The high amount of fine/ forced payment do not guarantee that society becomes afraid or discouraged.

Pertaining to the conclusion described above, there are several recommendations as follows:

1. The Regional government of Bandung City needs to find a right model to keep sidewalk vendors in order especially on the streets and green line by looking at the characteristics of the society and its social culture.

2. The Regional government of Bandung City needs to search for a way to increase society's compliance to any policies made by the government.

3. There is a need to change of the Regional Government Regulation on Order, Cleanliness and Esthetic and Regional Government Regulation on Sidewalk Vendors in relation to the definition of sidewalk vendors and the inclusion of forced payment and fine.

\section{REFERENCE}

Ali, Achmad. 2012. Menguak Teori Hukum (legal Theory) dan Teori Peradilan (Judicial prudence) Termasuk Interpretasi UndangUndang (Legis prudence). Jakarta: Kencana Prenada.

Winarno, Budi. 2002. Apakah Kebijakan Publik? Dalam Teori dan Proses Kebijakan Publik. Yogyakarta: Media Pressindo.

Eka Puspitasari, Dinarjati. 2010. "Penataan Pedagang Kaki Lima Kuliner untuk Mewujudkan Fungsi Tata Ruang Kota di Yogyakarta dan Kabupaten Sleman" Mimbar Hukum, Volume 22, Number 3, October 2010.

M Setiadi, Elly and Usman Kolip. 2013. Pengantar Sosiologi, Pemahaman Fakta dan Gejala Permasalahan Sosial: Teori Aplikasi dan Pemecahannya. Jakarta: Kencana Prenada Media Group.

Achjani Zulfa, Eva. 2011. Pergeseran Paradigma Pemidanaan. Bandung: Lubak Agung.

Asshiddiqie, Jimly dan M Ali Safa'at. 2006. "Teori Hans Kelsen Tentang Hukum", Secretariat General and Secretary, Constitutional Court of Republic of Indonesia RI. 
Muladi. 1995. Kapita Selekta Hukum

Pidana. Semarang: Badan Penerbit Universitas Diponegoro.

Hanitjo Soemitro, Ronny. 1990. Metodologi Penelitian Hukum dan Jurimetri. Jakarta: Penerbit Ghalia.

Soekanto, Soerjono. 1982. Pengantar Penelitian Hukum Edisi Kedua. Jakarta: UI Press.

-------, Faktor-Faktor yang Mempengaruhi Penegakan Hukum (Inauguration Speech as Professor at Law Faculty in University of Indonesia). 2008. Jakarta: PT Raja Grafindo Persada.

Soekanto, Soerjono dan Sri Mamudji. 1985. Penelitian Hukum Normatif suatu Tinjauan Singkat. Jakarta: Penerbit Rajawali.

Mertokusumo, Sudikno. 1993. Bab-Bab tentang Penemuan Hukum. Yogyakarta: Citra Aditya Bakti.

Haryono, Tulus. 1989. Faktor-Faktor yang Mempengaruhi Keberhasilan Usaha Pedagang Kaki Lima, Studi Kasus di Kodya Surakarta. Yogyakarta: UGM Press. 